Journal of Science Education Research

Journal homepage: www.journal.uny.ac.id/jser

JSER

\title{
Identification of the Conceptual Understanding of the Uniformly Accelerated Rectilinear Motion (GLBB) Material Using PhET Application and the VAK Learning Model among Junior High School Students
}

\author{
Eka Nurlita Anggraeni, Inggrid Ayu Amala, Iwan Wicaksono, and Aris Singgih Budiarso \\ Natural Science Education, Jember State University, J1.Kalimantan No. 37, Jember 68121, Indonesia \\ Corresponding Author. Email: ekaanggraini41@ gmail.com
}

\section{Keywords: \\ PhET application, \\ VAK model, the \\ Uniformly \\ Accelerated \\ Rectilinear \\ Motion (GLBB)}

\begin{abstract}
Junior high school students find it difficult to understand the materials and the concepts in science learning because the teaching method that is too monotonous. It is the lecturing method where students are less involved in learning activities, and this has led to the decline in students' learning outcomes in science learning. The use of media and learning models play an important role. The popular media in learning are modern media, in this case PhET application. This application can give the impression of a direct experiment among students without ignoring technological developments where IT is needed by students. This study aims to identify students' conceptions on concepts. The type of this research was a library research. This study used the VAK learning model (Visual, Auditory, and Kinesthetic). In the VAK learning model, the teacher can combine three teachinglearning styles. 1) The teacher will prioritize the demonstration or the media by showing the teaching tools directly to the students and describing them on the board. 2) In learning by listening, the teacher must be able to explain clearly and in detail so that the students can understand the material presented. 3) In learning practice, after the students listen and learn through physical activity and direct involvement, they must conduct a direct experiment to gain deeper understanding of the materials. In this library research, the researchers searched for some references related to the research.
\end{abstract}

C2018 JSER. Yogyakarta State University

\section{INTRODUCTION}

Current teaching-learning conditions require human resources that meet educational needs. Junior high school students often have difficulty understanding the material on the Uniformly Accelerated Rectilinear Motion (GLBB). In GLBB teaching-learning process, the teachers often do monotonous teaching methods and do not involve in the teaching-learning activities with the students.

In Natural Science Subjects (Sciences), students must have some abilities, such as observing pictures and videos or writing. Writing is basically an important thing in education because it helps students to think creatively and innovatively in developing their writing. Then the students should have the ability to listen to what is conveyed by the teacher. The students must be able to listen to what is explained by the teacher by increasing their concentration. The students should also be able to practice what has been written and also heard so that the materials explained by the teacher can be fully understood.

In schools, those abilities are hard to implement because of the lack of concentration of the students and also lessons considered difficult by the students. Thus the teacher must be able to design a teaching-learning model that can attract the students' attention. The teaching-learning model designed by the teacher should be able to keep the students' focus on the lessons delivered so that the materials can be well understood. 
This VAK (Visual, Auditory, and Kinesthetic) model is a very smart solution where the three tendencies of one's learning style are combined. The way to improve students' creative thinking skill through this VAK model is by utilizing audio and visual media and through movement activities that make the three teachinglearning styles optimally coordinated. This teachinglearning model is facilitated by PhET. By using PhET, students will be able to see and practice the concept of GLBB because it has been equipped with moving images, which are easier to understand, so that there will be no more misconception on GLBB.

In this teaching-learning model, students will be presented with three direct learning styles, namely: 1) Visual, learning by seeing, 2) Auditory, learning by listening; 3) Kinesthetic, learning by moving, working, and touching. PhET can represent the visual and kinesthetic styles. Thus, it is expected that with the VAK learning model and PhET application, students can understand the concept better. In addition, students' abilities and mastery of the concept of GLBB can be improved.

\section{METHOD}

Basically, this section explains how the research was conducted. The substance of this section covers (1) research design, (2) population and sample (research target), (3) techniques of data collection and instrument development, (4) and data analysis techniques. For research using tools and materials, it was necessary to write down the specifications of the tools and materials. The specifications of the tools described the sophistication of the tools, while the specifications of the materials described the types of the materials.

In the qualitative research, such as classroom action research, experiments, research and development (R\&D), and case studies, it was necessary to add the presence of the researchers, research subjects, informants who helped in the research, methods to explore the research data, location and duration of the study, and description of how to check the validity of the research results.

\section{RESULT}

Based on a number of relevant articles or reference, the use of the VAK model and PhET application has a positive impact on the understanding of junior high school students. According to (Rahayu, 2017), the VAK learning model (Visual, Auditory, and Kinesthetic) is a teaching-learning model that combines the three learning styles possessed by everyone. Basically, this model is developed to accommodate all student learning styles so that the students can receive the teaching-learning process more effectively based on the abilities of the students.

The problem that occurs in a teachinglearning process is that the students' learning styles do not gain attention from the teacher. In fact, the diverse learning styles of students are important factors to consider in a teaching-learning process. Without having enough knowledge about the students' learning styles, the teacher cannot provide varied learning instructions. According to (Rusnayati, 2016), learning style is related to how to collect, process, interpret, organize, and think of information. Learning style is a characteristic performed by someone in learning. There are several theories about learning styles, one of which is the VAK (Visual, Auditory, and Kinesthetic). The VAK learning model divides learning styles into three major groups, namely: seeing (visual), listening (auditory), and doing (kinesthetic). In a research conducted by Young in 2006, it is concluded that the teaching-learning method that meets the preferred learning style can improve learning achievement and self performance. Therefore, learning styles are one of the important factors in the teaching-learning process.

Based on the research conducted by (Rahmawati, 2017), the VAK learning model provides better learning outcomes than the lecturing method. This is because in the VAK learning model, the students not only listen but also work and see pictures or videos that have been prepared so that the concepts received are consonant with what is expected by the teacher.

It is supported by a research carried out by (Widodo, 2016) stating that in teaching-learning activities, the VAK model in both low and high classes can instill independent and creative values in the students without the teacher giving explanation about the notions of independent and creative values. The students indirectly have implemented independent and creative values from the stages of the learning model and conditions created by the teacher. To give the students more understanding of independent and creative values, the teacher needs to provide an explanation of the impact if they do not carry out activities that contain independent and creative values. Thus, the students will think that they need to implement independent and creative values in each of their activities.

The use of PhET as a medium can affect the level of understanding and learning outcomes of junior high school students. PhET can help the teaching-learning process in physics on the Uniformly Accelerated Rectilinear Motion. Physics is one branch of sciences that scares students. It makes students less interested in learning. In addition, it is difficult for students to understand because there are many formulas that they must 
master from the real to the abstract ones. Therefore, the students should really understand the concepts taught by the teacher. If the students do not understand the concepts, it will have an impact on students' learning outcomes such as in the material of nuclear physics. Conceptual understanding or the ability of a person to understand something after it is known or remembered includes the ability to grasp the meaning of the materials being studied which is expressed by describing the main contents of a reading or by changing the data presented in certain forms to other forms (Sudaryono, 2012).

PhET presents various kinds of science material simulations, one of which is a physics simulation that can explain the abstract concepts in physics or materials that are difficult to perform in the experiments in real laboratories. The simulations in PhET application used in this study are the simulations of the materials on electrics and magnet. To facilitate and guide the students in searching for the values in physics in PhET simulation, the observation sheets are developed and must be filled out by the students during the learning activities (Widyaningsih, 2018).

Similarly, a research conducted by Syaifulloh (2014) also shows that the teaching-learning method with PhET receives good response from the students and provides better learning outcomes. The students are more excited and interested in learning physics using PhET application. In addition, it is easier for the teacher to teach the Uniformly Accelerated Rectilinear Motion to the students with a virtual laboratory. The teacher also does not need to worry about using tools because it is not necessary to conduct the experiments in the real laboratory.

Iryani (2018) in her article also states that learning with the help of PhET simulations effectively remediates misconceptions among students. The utilization of PhET as a virtual laboratory also improves students' understanding of a concept. This is because experiments with PhET will be able to produce accurate data and also not be influenced by external factors so that errors in the experiments can be minimized. Therefore, the students gain knowledge that is in accordance with the concept.

The medium used is PhET application to improve students' understanding of motion materials. $\mathrm{PhET}$ is a simulation made by the University of Colorado that contains simulations of physics, biology, and chemistry for the benefit of classroom teaching or individual learning. PhET simulation emphasizes the correlation between the real-life phenomena and the underlying science, supports interactive and constructive approaches, gives feedback, and provides a creative workplace (Finkelstein, 2006). The choice of media in a teaching-learning process must be considered because it affects the conceptual understanding of students and students' learning outcomes. Hence, the selection of media is important in the teachinglearning activities carried out by a teacher and the students.

\section{CONCLUSIONS}

Based on the references compiled, the VAK learning model using PhET application can increase students' interest in learning so that they can optimally absorb the materials. By using PhET application, students can play while learning because they can conduct experiments which make the teaching-learning process interesting. They will also study harder.

\section{REFERENCES}

Rahayu, M,D., Riyana, C,. \& Silvana, H. 2017. Efeltifitas Penerapan Model Pembelajaran VAK (Visual, Auditory, and Kinesthetic) terhadap Peningkatan Kemampuan Berpikir Kreaaif Siswa pada Mata Pelajaran Bahasa Indonesia. Edutcehnologia. Volume 3 No 2.

Sandhi, A, M,. Djuanda, D,. Surnarya, D, T,. 2017. Penerapan Metode Think Pair Share dengan Media Visual untuk Meningkatkan Keterampilan Berbicara. Jurnal Pena Ilmiah. Vol 2, No 1.

Rahmawati, K, N,. 2017. Penerapan Model Pembelajaran Matematika Menggunakan Model SAVI dan VAK pada Materi Himpunan Terhadap Prestasi Belajar Siswa Kelas VII. Jurnal Ilmiah Pendidikan Matematika. Volume 5 Number 2. .ISSN:2548-3994

Iryani, I., Tandililing, E., \& Hamdani, H. 2018. Remediasi Miskonsepsi Siswa dengan Model Pembelajaran Children Learning in Science (CLiS) Berbantuan Simulasi PhET. Jurnal Pendidikan dan Pembelajaran, 7(4).

Widyaningsih, S. 2018. Penerapan Simulasi Phet Terhadap Hasil Belajar Mahasiswa pada Mata Kuliah Fisika II Di Program Studi Ilmu Kelautan Universitas Papua. Berkala Ilmiah Pendidikan Fisika Volume 6(2): 180-188. 